\title{
Multilateralismo, crise e migração venezuelana: o Grupo de Lima e o Processo de Quito em perspectiva comparada.
}

\section{Multilateralism, crisis, and Venezuelan migration: the Lima Group and the Quito Process in a comparative perspective.}

Resumo: Este trabalho analisa em perspectiva comparada os discursos e as respostas oferecidas por parte do Grupo de Lima (GL) e o Processo de Quito (PQ) respeito à crise e a migração venezuelana no período 2017-2020. Ambos os espaços multilaterais emitiram declarações conjuntas e estabeleceram compromissos, ao passo que promoveram a articulação com organizações internacionais em matéria de migração e refúgio. Contudo, entre os dois processos existem diferenças importantes quanto às suas posições políticas em relação ao atual Governo da República Bolivariana da Venezuela, seus objetivos, formas de funcionamento e o grau de centralidade que atribuem à questão migratória. Para tal, o texto discute teoricamente o fenômeno do multilateralismo, seus vínculos com as migrações e fenômenos como o multilateralismo contestado. Metodologicamente utilizou-se a análise documental e de conteúdo qualitativa de declarações, comunicados e artigos de imprensa e a análise de dados secundários da Plataforma R4V e da ENCOVI. Os resultados apontam que embora América Latina conte um uma longa tradição de cooperação multilateral, tanto o GL quanto o PQ constituem mecanismos ad hoc que transcendem os espaços tradicionais de abordagem das crises e das migrações a nível regional.

Palavras-chave: Migrações. Multilateralismo. Venezuela. Grupo de Lima. Processo de Quito.

Abstract: This paper analyzes in a comparative perspective the discourses and responses offered by the Lima Group (GL) and the Quito Process (PQ) regarding

\footnotetext{
* Doutora em Ciência Política pela Universidade Complutense de Madrid (UCM). Professora do Programa de Pós-graduação em Ciência Política da Universidade Federal do Estado do Rio de Janeiro (UNIRIO). Bolsista de Pós-doutorado Nota 10 da Fundação de Amparo à Pesquisa do Estado do Rio de Janeiro (FAPERJ). Coordenadora do Grupo de Relações Internacionais e Sul Global (GRISUL) e Pesquisadora do Núcleo Interdisciplinar de Estudos Migratórios (NIEM). Email: maria.villarreal@unirio.br
} 
the Venezuelan crisis and migration in the period 2017-2020. Both multilateral spaces, issued joint statements and established commitments, whilst promoting articulation with international organizations on migration and refugee issues. However, between the two processes there are important differences in terms of their political positions in relation to the current government of the Bolivarian Republic of Venezuela, their objectives, their ways of functioning, and the degree of centrality they attribute to the migration issue. To this end, the text theoretically discusses the phenomenon of multilateralism, its links with migration and phenomena such as contested multilateralism. Methodologically, we used documentary and qualitative content analysis of statements, press releases and articles and secondary data analysis of the R4V Platform and ENCOVI. The results show that although Latin America has a long tradition of multilateral cooperation, both the Lima Group and the Quito Process are ad hoc mechanisms that transcend the traditional spaces for addressing crises and migration at the regional level.

Keywords: Migration. Multilateralism. Venezuela. Lima Group. Quito Process.

\section{Introdução}

A Venezuela experimenta hoje uma crise econômica, política e humanitária sem precedentes (PÁEZ; VIVAS, 2017; LANDER, 2018; BAENINGER; JAROCHINSKI, 2018; KOECHLIN; EGUREN, 2018; GANDINI, et al. 2019; ACOSTA, et al. 2019; ENCOVI, 2019; VILLARREAL, 2019a, 2019b; ACNUR, 2020; OIM, 2020; SMILDE; RAMSEY, 2020) e o êxodo venezuelano soma mais de cinco milhões e meio de pessoas com perspectivas de contínuo crescimento $^{1}$ (R4V, 2021).

A diferença do presente, historicamente o Estado andino² foi um país de imigrantes. Durante os séculos XIX e, sobretudo no século XX, a Venezuela recebeu milhões de pessoas provenientes da Europa, Oriente Médio, Ásia e

\footnotetext{
${ }^{1}$ Até a atualização de 05/02/2021 da Plataforma de Coordenação para Refugiados e Migrantes da Venezuela, a cifra de migrantes, refugiados e solicitantes de refúgio venezuelanos reconhecida pelos países de recepção era de 5.478.377. Contudo, se trata de um número aproximado, e as estimativas da Plataforma falam de um cifra superior aos seis milhões de migrantes $(\mathrm{R} 4 \mathrm{~V}, 2021)$. É importante frisar que, através desta Plataforma, que reúne atualmente a 151 atores no âmbito regional e nacional, é realizada a coordenação da resposta para refugiados e migrantes da Venezuela.

2 Além de ser um país andino pela presença da Cordilheira dos Andes, devido à sua heterogênea geografia, a Venezuela é também considerada uma nação caribenha, atlântica e amazônica.
} 
Revista Brasileira de História \& Ciências Sociais - RBHCS

Vol. 13 No 26, Janeiro - Junho de 2021

América Latina, ganhando o título de "país de portas abertas"3 (TORREALBA et al. 1983; PÁEZ, 2015). Não obstante, desde finais do século XX e começos do século XXI, a Venezuela passou de ser um dos maiores receptores de imigrantes da América Latina a ser o principal país de emigração na região e um dos principais do mundo.

A migração venezuelana contemporânea tem alcance global (PÁEZ, 2015; PÁEZ; VIVAS, 2017; BAENINGER; JAROCHINSKI, 2018; KOECHLIN: EGUREN, 2018; GANDINI, et al. 2019; ACNUR, 2020; OIM, 2020; R4V, 2021). Porém, seja pelas condições e características do fluxo migratório venezuelano (PÁEZ, 2015; PÁEZ; VIVAS, 2017; GANDINI, et al. 2019; ENCOVI, 2020), como consequência do fechamento das fronteiras e contínuas restrições por parte dos países do Norte (OIM, 2020; ACNUR, 2020), ou pela proximidade, menores custos e relativas "facilidades" à migração regional, a maioria dos migrantes venezuelanos se concentra na América Latina, fazendo deste fenômeno um desafio prevalentemente regional (ACOSTA, et al. 2019; VILLARREAL, 2018, 2019a, 2019b).

Desafios como o gerado pela migração venezuelana não podem ser abordados apenas de forma unilateral ou bilateral, se não que precisam da cooperação multilateral. No âmbito global, América Latina tradicionalmente tem sido um ator central do multilateralismo. Algumas das contribuições regionais mais salientes são a elaboração de normas de Direito Internacional e o seu histórico de regionalismo e solução pacífica das controvérsias (ROJAS, 2000; VAN KLAVEREN, 2018, 2020). A região teve também um papel chave na promoção do multilateralismo através da criação de organizações internacionais que contribuíram de forma significativa para o desenvolvimento da ordem liberal antes e depois da Segunda Guerra Mundial (VAL; SLOBODA, 2015; VAN KLAVEREN, 2018, 2020).

A partir da segunda metade do século XX, os mecanismos regionais e hemisféricos foram centrais para abordar as crises e os desafios do subcontinente (ROJAS, 2000; VAL; SLOBODA, 2015; RIBEIRO, 2016; NOLTE,

3 Esta denominação ou a de "país de braços abertos" descreve, em particular, a política migratória vigente ao longo do período 1936-1960 que visava atrair principalmente imigrantes europeus. Outras fases da história do país se caracterizaram por tentativas frustradas de atração de população, especialmente europeia, e por restrições e maiores controles à imigração, mas sem invalidar a condição do país como histórico receptor de população intra e extrarregional (TORREALBA, et al. 1983). 
2019). Em particular, vale destacar a função exercida pela Organização de Estados Americanos (OEA), e o papel desempenhado por grupos sub-regionais ad hoc como o Grupo de Contadora e o Grupo de Apoio a Contadora, protagonistas nos processos de paz, transição democrática e segurança regional na América Central. Em 1986, ambas iniciativas confluíram no Grupo de Rio, um Mecanismo Permanente de Consulta e Concertação Política, que, segundo Rojas (2000), forma parte de outra expressão central do multilateralismo latino-americano: a diplomacia de cúpulas. Outros exemplos que vale a pena destacar são os casos do Mercado Comum do Sul (Mercosul), da União de Nações Sul-americanas (Unasul) e, mais recentemente da Comunidade de Estados Latino-americanos e Caribenhos (CELAC) e do Foro para o Progresso e Integração da América do Sul (Prosul). Seja mediante declarações ou a através de cláusulas democráticas, tais espaços assumiram responsabilidades a favor da governança regional e de respeito à democracia (VAN KLAVEREN, 2018, 2020; RIBEIRO, 2016; NOLTE, 2019).

O multilateralismo também tem sido utilizado para tratar fenômenos de importância crescente como as migrações. Na América Latina, Processos Consultivos Regionais (PCR) como o Processo de Puebla4 ou a Conferência Sulamericana de Migrações (CSM) são dois dos exemplos mais emblemáticos (MÁRMORA, 2010, 2016; OIM, 2021). Além disso, o Mercosul, a CAN e a Unasul também tem desempenhado um papel significativo na abordagem deste fenômeno (VILLARREAL, 2018). No entanto, apesar da adesão retórica ao multilateralismo, no âmbito regional o fenômeno entrou em crise, sobretudo a partir de 2016. Tal crise está vinculada a fatores como as contradições políticoideológicas internas ou às dificuldades na gestão das tensões regionais (NOLTE, 2019; ROMERO et al. 2020). Como resultado, na América Latina de hoje há um forte questionamento dos regimes internacionais e uma profunda crise da institucionalidade e dos mecanismos de integração regional (NOLTE, 2019; VAN KLEVEREN, 2020). Um sintoma desta crise, é que para o tratamento da situação venezuelana, não têm sido utilizados os meios tradicionais. No seu lugar, foram criadas iniciativas ad hoc como o Grupo de Lima (2017) e o Processo de Quito (2018). Isso não significa que não existam ações e respostas perante o fenômeno por parte de organizações como a OEA ou a CSM, mas

4 Também denominado Conferência Regional sobre Migração (CRM). 
Revista Brasileira de História \& Ciências Sociais - RBHCS

Vol. 13 No 26, Janeiro - Junho de 2021

diversos trabalhos (ACOSTA, et al. 2019; VILLARREAL, 2019a, 2019b; VAN KLEVEREN, 2020; ROMERO et al. 2020; BATALLAS, 2020; SILVA, DE SOUZA, 2020; BARBIERI et al. 2020; SMILDE; RAMSEY, 2020) têm evidenciado que as iniciativas ad hoc prevalecem sobre estas últimas.

Estes elementos servirão de orientação para a análise comparada dos discursos e respostas oferecidas pelo Grupo de Lima e o Processo de Quito em relação à crise e a migração venezuelana, durante o período 2017-2020. Quanto aos procedimentos metodológicos, utilizou-se a análise documental e de conteúdo qualitativa (BARDIN, 2016) de declarações, comunicados institucionais e artigos de imprensa. Paralelamente, foram também analisados dados secundários da Plataforma de Coordenação para Refugiados e Migrantes da Venezuela (R4V) e da Encuesta Nacional de Condiciones de Vida (ENCOVI) 2019-2020. A comparação é de tipo sincrônico e diacrônico (LANDMAN, 2011).

Além desta introdução e das conclusões, o artigo se estrutura em três seções. Na primeira, serão oferecidas algumas noções teóricas sobre multilateralismo e migrações. Em segundo lugar, serão descritas algumas das principais características da Venezuela e do êxodo venezuelano contemporâneo. Por último, na terceira seção serão analisadas em perspectiva comparada as ações e respostas do Grupo de Lima e do Processo de Quito em relação à crise e a migração venezuelana.

\section{Multilateralismo e migrações}

O multilateralismo é uma prática e princípio fundamental das Relações Internacionais que surge no século XIX e se consolida no século XX a partir de três princípios básicos: a não discriminação, a indivisibilidade e a difusão recíproca (GRIFFITHS; O'CALLAGHAN, 2002; FERNANDES; SIMÃO, 2019). O primeiro princípio se refere ao dever de cumprir as obrigações dos acordos alcançados sem exceções ou concessões devido às contingências. $O$ segundo diz respeito ao cumprimento dos compromissos adquiridos a partir de acordos coletivos e indivisíveis, por exemplo, em matéria de paz e segurança coletiva. Finalmente, o princípio da reciprocidade difusa implica que a continuidade na aplicação dos princípios de não discriminação e indivisibilidade é um ingrediente essencial dos acordos multilaterais (GRIFFITHS; O'CALLAGHAN, 2002). 
O fenômeno do multilateralismo tem múltiplas definições e é analisado de forma diferenciada pelas várias escolas de pensamento das Relações Internacionais (FERNANDES; SIMÃO, 2019). O multilateralismo pode ser definido como "a prática de coordenação de políticas nacionais em grupos de três ou mais Estados por meio de arranjos ad hoc ou por meio de instituições" (KEOHANE, 1990, p. 71, tradução nossa). 5 Por sua vez, Ruggie (1992), define o multilateralismo como "uma forma institucional que coordena as relações entre três ou mais Estados com base em princípios "generalizados" de conduta, ou seja, princípios que especificam a conduta apropriada para uma classe de ações, sem relação aos interesses particulares das partes ou às exigências estratégicas que podem existir em qualquer ocorrência específica" (RUGGIE, 1992, p. 571, tradução nossa). ${ }^{6}$

No contexto do pós-guerra Fria, desafios globais como o comércio internacional, os direitos humanos ou o meio ambiente, permitiram um aprofundamento do multilateralismo, principalmente no âmbito regional. Contudo, fatores como a reestruturação da estrutura de poder em termos globais, a crise da ordem liberal e o aumento de tendências soberanistas têm contribuído a gerar uma crise do multilateralismo, aprofundada no contexto da Covid-19 (FERNANDES; SIMÃO, 2019; VAN KLEVEREN, 2020; ROMERO et al. 2020). Embora este fenômeno não afete a todos os continentes da mesma forma7, autores como Newman (2007, p. 15) falam de um "mal-estar multilateral", causado pelos múltiplos desafios enfrentados pelo "modelo convencional de soberania do Estado”. Por sua parte, Rüland (2012, p. 256) utiliza a expressão "multilateralismo diminuído" para definir um processo marcado por disputas cada vez mais intensas. Tais disputas versam sobre a composição e a representação, assim como sobre as normas e processos de

\footnotetext{
5 "Multilateralism can be defined as the practice of coordinating national policies in groups of three or more states through ad hoc arrangements or by means of institutions" (KEOHANE, 1990, p. 731).

6 "Multilateralism is an institutional form which coordinates relations among three or more states on the basis of "generalized" principles of conduct-that is, principles which specify appropriate conduct for a class of actions, without regard to the particularistic interests of the parties or the strategic exigencies that may exist in any specific occurrence" (RUGGIE, 1992, p. $571)$.

7 A diferença do que acontece na América Latina, na Ásia o multilateralismo experimenta uma boa fase, especialmente nas áreas econômica, financeira e comercial, assim como em relação à setores quais a infraestrutura e a conectividade física (RANA, 2020).
} 
tomada de decisão, fazendo das instituições internacionais arenas de lutas de poder.

Morse e Keohane (2014) falam também de "multilateralismo contestado" para descrever a situação "que resulta da busca de estratégias por parte de Estados, organizações multilaterais e atores não-estatais para usar instituições multilaterais, existentes ou recém-criadas, com o fim de desafiar as regras, práticas ou missões de instituições multilaterais preexistentes" (MORSE e KEOHANE, 2014, p. 385, tradução nossa). ${ }^{8} \mathrm{O}$ desafio começa com a ameaça de saída, até a criação de novas instituições que facilitem novas práticas. Para os autores, o multilateralismo contestado assume duas formas principais: mudança de regime e criação de regime competitivo e se registra em múltiplas áreas como o comércio internacional, o meio ambiente ou a saúde global. As razões que motivam a insatisfação com o status quo são principalmente exógenas, e as instituições usadas para desafiá-lo podem incluir tratados tradicionais ou organizações intergovernamentais e redes informais, algumas das quais incluem atores não estatais. Neste processo, enquanto algumas instituições podem ser beneficiadas, outras podem perder autoridade ou status. Desde começos do século XXI, esta prática tem sido amplamente utilizada no âmbito latino-americano, com a criação de organismos como a Aliança Bolivariana para os Povos da Nossa América (ALBA), a Aliança do Pacífico, a Unasul e a CELAC (NOLTE, 2019, p. 135).

Por outro lado, o tratamento das migrações internacionais acontece de forma crescente no âmbito multilateral. O aumento dos fluxos migratórios tem efeitos sobre as interações diplomáticas dos Estados com outros atores do sistema internacional e se torna objeto da diplomacia interestadual, dando origem muitas vezes à diplomacia da migração (migration diplomacy), isto é, o uso de ferramentas diplomáticas, processos e procedimentos para gerenciar a mobilidade populacional transfronteiriça (ADAMSON e TSOUPARAS, 2019, p. 115-116).

\footnotetext{
8 "Contested multilateralism" describes the situation that results from the pursuit of strategies by states, multilateral organizations, and non-state actors to use multilateral institutions, existing or newly created, to challenge the rules, practices, or missions of existing multilateral institutions. It occurs when coalitions dissatisfied with existing institutions combine threats of exit, voice, and the creation of alternative institutions to pursue policies and practices different from those of existing institutions (MORSE; KEOHANE, 2014, p. 385).
} 
Revista Brasileira de História \& Ciências Sociais - RBHCS

Vol. 13 No 26, Janeiro - Junho de 2021

A governança da migração é também uma derivação das discussões sobre governança global e implica a cooperação internacional em matéria migratória a partir de um amplo mosaico de instituições e estruturas formais e informais que operam nos níveis bilateral, regional, inter-regional e multilateral (BETTS, 2011). No âmbito regional, a governança das migrações tem evoluído de forma paralela ao processo global de cooperação em matéria de migração e se desenvolve no marco regulatório internacional do fenômeno, sob a égide de organismos internacionais como a Organização Internacional para as Migrações (OIM) ou o Alto Comissariado das Nações Unidas para Refugiados (ACNUR) (GRANJA; VILLARREAL, 2017). Na América Latina e no Caribe, além da presença dos governos e dos organismos internacionais especializados no fenômeno, envolve a participação crescente da sociedade civil, governos locais e, desde a década de 1990, conta com atores chave como os diversos Processos Consultivos Regionais (PCR) em matéria de migrações (ver figura 1).

\section{Figura 1. Processos Consultivos Regionais (PCR) na América Latina e no Caribe}

\begin{tabular}{cc}
\hline Nome do PCR & Ano de criação \\
\hline $\begin{array}{c}\text { Comissão Centro-americana de Diretores de } \\
\text { Migração (OCAM) }\end{array}$ & 1990 \\
\hline $\begin{array}{c}\text { Conferência Regional sobre Migração (CRM) } \\
\text { ou Processo de Puebla }\end{array}$ & 1996 \\
$\begin{array}{c}\text { Conferência Sul-americana de Migrações } \\
\text { (CSM) ou Processo de Lima } \\
\text { Caribbean Migration Consultations }\end{array}$ & 2000 \\
\hline
\end{tabular}

Elaboração própria. Fonte: OIM (2021).

No caso específico da América do Sul, autores como Mármora (2010) argumentam que esses processos de diálogo geraram um modelo de governança único, baseado na perspectiva do desenvolvimento humano da migração. Tal modelo estaria baseado em uma posição consensual entre os governos da subregião que defende a perspectiva dos direitos humanos no tratamento integral e coerente da migração, enfatizando a liberdade de locomoção e residência dos cidadãos sul-americanos, mas também seus direitos sociais e de participação 
política por meio das propostas de ampliação da cidadania surgidas no Mercosul, CAN e Unasul (VILLARREAL, 2018). A existência de problemas de implementação das normas e de concretização dos discursos, a clara hierarquia estabelecida entre os cidadãos extra e intrarregionais e a permanência de fenómenos como a discriminação, o racismo e mesmo a deportação e expulsão de pessoas, têm colocado em discussão esta visão excessivamente otimista, gerando diversos questionamentos em relação ao modelo regional (DOMENECH, 2013，2017; GRANJA; VILLARREAL，2017; VILLARREAL, 2018).

Apesar de uma longa tradição multilateral latino-americana na abordagem do fenômeno migratório, o que nos interessa destacar a fins deste trabalho é que, como resultado da crise do multilateralismo e de fenômenos como o "multilateralismo contestado", a crise venezuelana e o êxodo originário do país andino não têm sido abordados nos espaços tradicionalmente utilizados para este fim. Em alternativa foram criados mecanismos ad hoc como o Grupo de Lima ou o Processo de Quito. Para entender parte deste processo é essencial conhecer, em primeiro lugar, algumas das características e implicações da migração venezuelana que veremos a seguir.

\section{A Venezuela e o êxodo venezuelano hoje}

Após a morte de Hugo Chávez em 2013 e a eleição de Nicolás Maduro, a Venezuela experimenta uma crise política, econômica e humanitária sem precedentes na história do país (LANDER, 2018; BAENINGER; JAROCHINSKI, 2018; KOECHLIN; EGUREN, 2018; GANDINI, et al. 2019; ACOSTA, et al. 2019; ENCOVI, 2019; ACNUR, 2020; OIM, 2020; SMILDE; RAMSEY, 2020). De acordo com Lander (2018, p. 233), as crises políticas e econômicas preexistentes no país sul-americano se aprofundaram sobretudo a partir de 2016 com a queda da economia em uma porcentagem estimada entre 10 e $18.6 \%$ do PIB e uma inflação de entre 300 e $800 \%$. Esta deterioração generalizada da economia, agravada pela queda do preço do petróleo, coincidiu com o aumento da insegurança e a acentuação das tendências autoritárias e a repressão por parte do governo de Nicolás Maduro. Tais fatores, somados às sanções econômicas que o país experimenta desde 2017, sobretudo por parte dos 
Revista Brasileira de História \& Ciências Sociais - RBHCS

Vol. 13 No 26, Janeiro - Junho de 2021

Estados Unidos e da União Europeia, provocaram profundos impactos na vida da população venezuelana (LANDER, 2018).

Como resultado, segundo a Encuesta Nacional de Condiciones de Vida (ENCOVI) 2019-2020, a partir da linha de pobreza, o 96\% dos lares venezuelanos pode ser considerado em situação de pobreza e $79 \%$ em situação de extrema pobreza. A Venezuela é hoje o país mais pobre e o segundo mais desigual da América Latina, e 79,3\% dos venezuelanos não tem como adquirir uma cesta básica de alimentos. Uma das consequências mais dramáticas deste processo é a massiva saída de pessoas. Pelo volume e a velocidade com a qual acontece, a migração venezuelana constitui o maior êxodo da história da América Latina (PÁEZ, 2015; PÁEZ; VIVAS, 2017).

Embora a maior parte da migração venezuelana seja forçada, a atual fase se caracteriza pela coexistência de fluxos mistos (forçados e não) e tem caráter global (PÁEZ, 2015; BAENINGER; JAROCHINSKI, 2018; KOECHLIN: EGUREN, 2018; GANDINI, et al. 2019; ACOSTA et al, 2019; OIM, 2020; ACNUR, 2020), mas 85\% se concentram nos países da América Latina e do Caribe (R4V, 2021). Com efeito, embora existam importantes comunidades de venezuelanos em países como Estados Unidos e Espanha, a maior parte do êxodo tem caráter intrarregional (Ver Gráfico 1). 
Revista Brasileira de História \& Ciências Sociais - RBHCS

Vol. 13 No 26, Janeiro - Junho de 2021

\section{Gráfico 1. Total de migrantes e refugiados nos 14 destinos principais da migração venezuelana na América Latina e no Caribe}

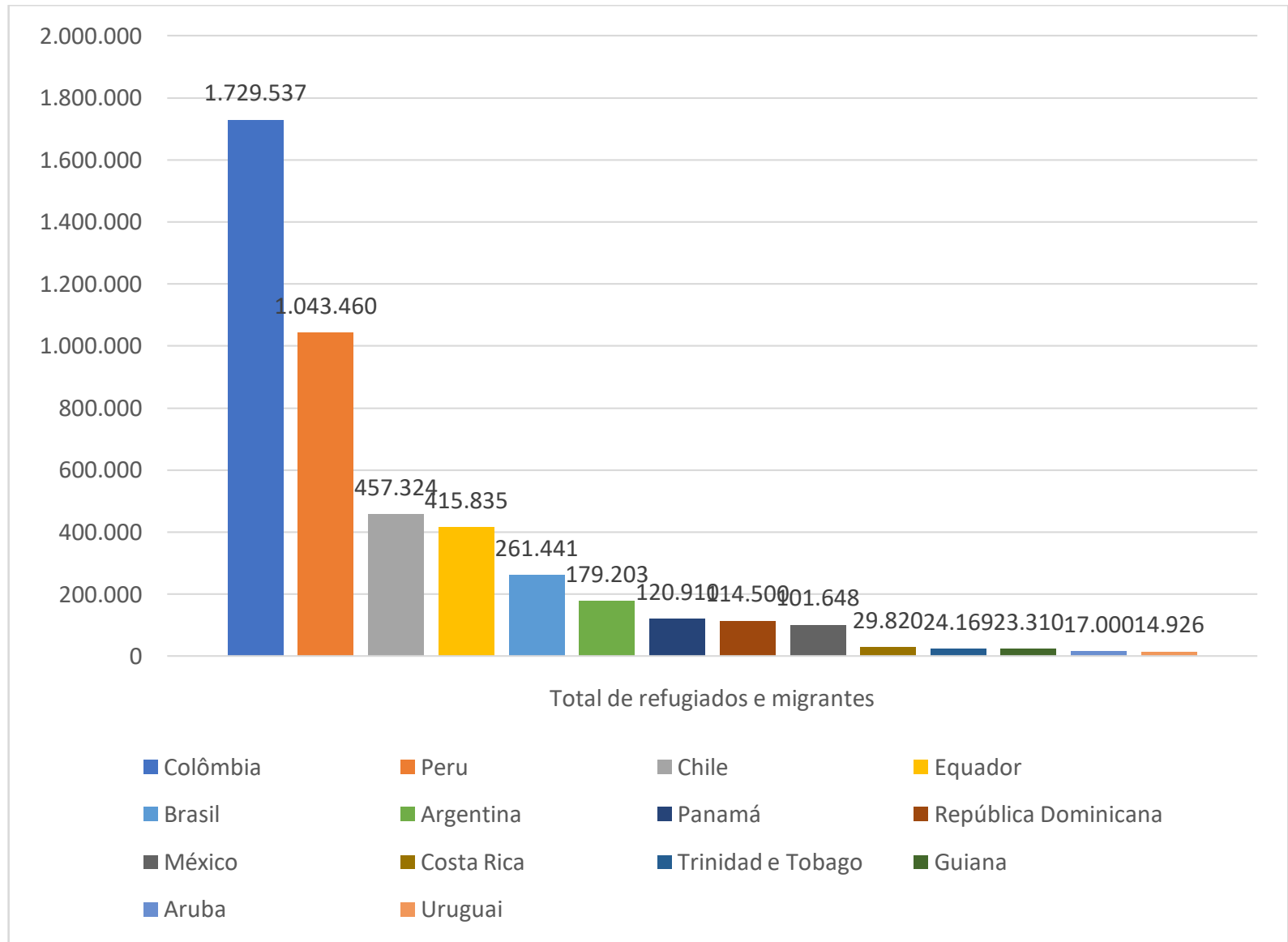

Elaboração própria. Fonte R4V (2021).

Hoje, a importância da migração em termos sociais é tal que um de cada cinco lares venezuelanos afirma que um o mais membros da sua família saíram do país no período 2014-2019 e 10\% das famílias venezuelanas são receptoras de remessas. Por outro lado, o cenário da Covid-19, caracterizado por fortes restrições à mobilidade humana (interna e internacional), tem contribuído ao agravamento da dramática situação do país sul-americano ao ponto que o desemprego aumentou $6.9 \%$, enquanto $43 \%$ dos lares venezuelanos declaram não ter possibilidades de trabalhar ou ter experimentado uma significativa perda de ingressos (ENCOVI, 2019-2020). Nesse contexto que afetou também os demais países latino-americanos e caribenhos, se registrou o retorno de mais de cem mil venezuelanos (OEA, 2020) ${ }^{9}$, mas apesar das restrições a migração

\footnotetext{
9 De acordo com o relatório do organismo, até setembro de 2020, se registrou o retorno oficial de 105.000 mil venezuelanos da Colômbia e de mais de 6.000 provenientes do Brasil (OEA, 2020, p. 4).
} 
Revista Brasileira de História \& Ciências Sociais - RBHCS

Vol. 13 No 26, Janeiro - Junho de 2021

continua e enquanto permaneçam as causas que motivam a saída de população, este fenômeno está longe de acabar.

\section{Respostas multilaterais à crise e ao êxodo venezuelano: o Grupo de Lima e o Processo de Quito}

A crise multidimensional que experimenta a Venezuela e o êxodo originário do país sul-americano têm sido abordados em espaços tradicionais de cooperação multilateral como a Organização de Estados Americanos (OEA). Com o agravamento progressivo da crise venezuelana, em 26 de abril de 2017, o Conselho Permanente da OEA convocou uma reunião dos Ministros de Relações Exteriores, mas a Venezuela anunciou sua saída do organismo no mesmo dia. Além disso, a divisão interna entre os Países Membros da OEA e a ausência de uma maioria qualificada, impediu a ativação da Carta Democrática Interamericana em relação à situação do país (SILVA; DE SOUZA, 2019; BATALLAS, 2020; SMILDE; RAMSEY, 2020). Contudo, o organismo tem mantido um perfil ativo em relação à Venezuela e, em matéria migratória, atua em diversas áreas através de mandatos, o Programa Interamericano de Proteção dos Direitos Humanos dos Migrantes e entidades como a Comissão de Assuntos Migratórios (CAM).10

Por outro lado, apesar de que a Conferência Sul-americana de Migrações (CSM) é um processo consultivo regional de vital importância e que, ao longo da sua vigência tem sido o espaço privilegiado da governabilidade regional em matéria migratória (MÁRMORA, 2010, 2016), o fim da convergência ideológica entre os países da região, sua relativa paralise desde a XVIII Conferência de 2018, e os crescentes desafios gerados pelo êxodo venezuelano têm questionado seu papel como ator principal na orientação política dos Estados sul-americanos (ACOSTA et. al 2019; VILLARREAL, 2019a, 2019b; GANDINI, et al. 2019; BARBIERI et al. 2020; BATALLAS, 2020).

\footnotetext{
${ }^{10}$ Os diversos órgãos e entidades que conformam a OEA e abordam as questões migratórias são: Mandatos das Cúpulas das Américas - Migração; Comissão de Assuntos Migratórios (CAM); Programa de Migração e Desenvolvimento da OEA; Relatoria sobre os Direitos dos Migrantes; Programa Interamericano de Proteção dos Direitos Humanos dos Migrantes; Departamento de Segurança Pública da OEA; Comissão de Segurança Hemisférica da OEA - Tráfico de pessoas; e Sistema Contínuo de Relatórios sobre a Migração Internacional nas Américas (SICREMI) (OEA, 2021).
} 
Nesse contexto, os países da região têm criado respostas discricionais perante a migração venezuelana, enquanto no âmbito multilateral foram estabelecidas diversas iniciativas ad hoc. Em 2019'11, por exemplo, foram criados o Grupo de Contato Internacional (GCI) ${ }^{12}$ e o Mecanismo de Montevidéu. ${ }^{13}$ Entretanto, no âmbito regional, duas têm sido as iniciativas ad hoc protagonistas: o Grupo de Lima e o Processo de Quito (ACOSTA et. al 2019; VILLARREAL, 2019a, 2019b; BARBIERI et al. 2020; BATALLAS, 2020; SMILDE; RAMSEY, 2020).

O Grupo de Lima foi criado em 8 de agosto de 2017, sob a liderança do ex-presidente do Peru Pedro Paulo Kuczynski, como um instrumento da sua política externa em relação ao país sul-americano. Esta iniciativa é resultado da importância que adquire a migração no território deste Estado andino, posto que, como descrito anteriormente, o Peru constitui atualmente o segundo destino do êxodo venezuelano na região (R4V, 2021). Em termos operativos, o Grupo foi estabelecido como resultado da reunião convocada em Lima pelo exchanceler peruano Ricardo Luna, que contou com a participação de chanceleres e representantes de doze países: Argentina, Brasil, Canadá, Chile, Colombia, Costa Rica, Guatemala, Honduras, México, Panamá, Paraguai e Perú. Posteriormente se somariam a estes países Guiana, Santa Lucia, Haiti e Bolívia. A Declaração de Lima (ITAMARATY, 2017a) resultante do evento foi também endossada por Barbados, Estados Unidos, Granada, e Jamaica que assistiram ao encontro, assim como por organismos internacionais que participaram no evento como a OEA, a União Europeia e pela oposição venezuelana. ${ }^{14}$

\footnotetext{
${ }^{11}$ Em 2014, a Unasul e a Santa Sede promoveram um diálogo entre governo e oposição que contou com a participação dos chanceleres de Equador, Brasil e Colômbia, além de monsenhor Aldo Giordani, representante da Santa Sede na Venezuela. Após a tentativa frustrada promovida por estes atores, a Santa Sede (2016) e a República Dominicana (2017-2018), em 2019 aconteceu também a mediação dos diálogos entre governo e oposição por parte da Noruega e foi celebrada em Bruxelas a Conferência Internacional de Solidariedade sobre e Crise de Refugiados e Migrantes de Venezuela (SMILDE; RAMSEY, 2020).

${ }^{12}$ O GCI foi formado por iniciativa da União Europeia com o objetivo de coordenar esforços internacionais que busquem uma solução pacífica e democrática para a crise venezuelana por meio de novas eleições, de acordo com a Constituição do país. Atualmente formam parte desta instância multilateral diversos países da União Europeia (Alemanha, Espanha, França, Itália, Holanda, Portugal, Reino Unido e Suécia), e da América Latina como Costa Rica, Equador, Chile, Uruguai, Argentina, República Dominicana e Panamá (GARIP, 2020).

13 Este Mecanismo foi ativado por Uruguai, México e os países da Comunidade do CARIBE (Caricom). (SMILDE; RAMSEY, 2020).

14 Também assistiram à reunião de Lima, mas não subscreveram o documento os representantes de Guiana, Granada, Jamaica, Santa Lucía e Uruguai (BBC, 2017).
} 
Revista Brasileira de História \& Ciências Sociais - RBHCS

Vol. 13 No 26, Janeiro - Junho de 2021

Com a vitória de governos de direita e centro direita e a mudança do mapa político na região, o Grupo de Lima surgiu em um contexto de crescente fragmentação e crise dos organismos de concertação regional. Este processo não afetou apenas os organismos tradicionais como a OEA, mas também aqueles criados no marco do ciclo progressista como a Unasul ou a CELAC (VAN KLAVEREN, 2018, 2020; NOLTE, 2019, ROMERO et al, 2020). Além disso, o Grupo de Lima é também resultado de acontecimentos internos à Venezuela como a convocação por parte de Nicolás Maduro da Assembleia Nacional Constituinte que permitiu a consolidação do seu governo, após as eleições de 2015, em que o Parlamento eleito tinha sido de maioria opositora (SMILDE; RAMSEY, 2020).

De acordo com a Declaração de Lima (ITAMARATY, 2017a), o grupo tem o objetivo de abordar a situação crítica da Venezuela e explorar as formas de contribuir à restauração da democracia no país andino através de uma saída pacífica e negociada. Segundo este documento oficial "Animados pelo espírito de solidariedade que caracteriza a região e pela convicção de que a negociação, no pleno respeito das normas do direito internacional e do princípio da não intervenção, o qual não viola os direitos humanos e a democracia, é e o único instrumento que garante uma solução duradoura para as diferenças”, os países reunidos em Lima declararam entre outros propósitos, a condena da ruptura da ordem democrática na Venezuela, exigiram a libertação dos presos políticos e manifestaram seu compromisso de acompanhar a situação do país sulamericano até o pleno reestabelecimento da democracia (ver tabela 2). 
Tabela 2. Pontos da Declaração de Lima

1. Condenação do colapso da ordem democrática na Venezuela.

2. Decisão de não reconhecer a Assembleia Nacional Constituinte, ou os atos dela emanados, devido ao seu caráter ilegítimo.

3. Total apoio e solidariedade para com a Assembleia Nacional eleita democraticamente.

4. Reconhecimento dos atos jurídicos que, de acordo com a Constituição, carecem de autorização da Assembleia Nacional, só quando esta os tiver aprovado.

5. Forte rejeição à violência e qualquer opção que envolva o uso da força.

6. Apoio e solidariedade ao Procurador-Geral da República e aos membros do Ministério Público da Venezuela e exigência da aplicação das medidas cautelares emanadas da Comissão Interamericana de Direitos Humanos.

7. Condenação da violação sistemática dos direitos humanos e das liberdades fundamentais, da violência, repressão e perseguição política, da existência de presos políticos e da falta de eleições livres sob observação internacional independente. 8. Que a Venezuela não cumpre com os requisitos ou obrigações dos membros do Conselho de Direitos Humanos das Nações Unidas.

9. Grave preocupação pela crise humanitária que enfrenta o país e sua condenação ao governo por não permitir a entrada de alimentos e medicamentos em apoio ao povo venezuelano.

10. Decisão de continuar com a aplicação da Carta Democrática Interamericana à Venezuela.

11. Apoio à decisão do Mercosul de suspender a Venezuela em aplicação do Protocolo de Ushuaia sobre Compromisso Democrático.

12. Decisão de não apoiar nenhuma candidatura venezuelana em mecanismos e organizações regionais e internacionais.

13. Apelo para interromper a transferência de armas para a Venezuela à luz dos artigos 6 e 7 do Tratado sobre o Comércio de Armas.

14. Solicitação à Presidência Pro Tempore da CELAC e da União Europeia do adiamento da Cúpula CELAC-UE prevista para outubro de 2017.

15. Compromisso de acompanhar a situação na Venezuela, no âmbito dos Chanceleres, até o pleno restabelecimento da democracia naquele país, e de se reunir, o mais tardar, na próxima sessão da Assembleia Geral das Nações Unidas, oportunidade em que outros países poderão aderir.

16. Disposição de apoiar de maneira urgente e no marco do respeito à soberania venezuelana, todo esforço de negociação crível e de boa fé, que conte com o consenso das partes e que esteja orientado a alcançar pacificamente o restabelecimento da democracia no país.

Elaboração própria. Fonte: Declaração de Lima (ITAMARATY, 2017a).

Devido à sua natureza de mecanismo ad hoc, o Grupo de Lima não tem caráter vinculante, carece de institucionalidade e de uma presidência, mas é liderado pelo Peru, cujas autoridades convocam as reuniões de chanceleres e Estados Membros. No período 2017-2020, o Grupo realizou vinte reuniões, dando origem a mais de quarenta declarações, notas e comunicados. Contudo, as decisões do Grupo são concertadas e cada país pode assiná-las ou não. Exemplo disso é o fato de, após a posse de Andrés Manuel López Obrador, o país deixou de assinar os documentos e atualmente está desvinculado da 
iniciativa regional, justificando sua atuação a partir da Doutrina Estrada15. De forma paralela, a Venezuela começou a assinar os documentos desta instância multilateral a partir do reconhecimento do governo de Juan Guaidó em fevereiro de 2019. Por outro lado, o grupo pode buscar um consenso não só entre seus integrantes, mas também mobilizar outros países ou organizações. Por exemplo, obteve o apoio da União Europeia e da OEA diante do não reconhecimento do governo de Nicolás Maduro e tem emitido declarações conjuntas com o GCI.

Desde o seu estabelecimento, o Grupo de Lima está formado por países aliados e ideologicamente afins e tem assumido um perfil marcadamente político, constituindo também um mecanismo de alinhamento da política externa para os países opositores ao governo venezuelano como o Brasil e a Colômbia. Depois da suspensão da Venezuela no Mercosul ${ }^{16}$, a sua criação é considerada uma resposta perante as dificuldades da OEA em adotar medidas concretas respeito ao governo venezuelano, assim como uma alternativa à paralisia de organismos regionais como a Unasul, após a saída da maior parte de seus membros desde 2018 (SILVA; DE SOUZA, 2019; BATALLAS, 2020; SMILDE; RAMSEY, 2020). Porém, se no começo a Declaração de Lima (ITAMARATY, 2017a) apoiava a negociação, no pleno respeito das normas do direito internacional e do princípio da não intervenção, desde 2019 o Grupo considera inválidas as iniciativas de diálogo entre a oposição e o governo venezuelano presidido por Nicolás Maduro.

Após as eleições presidenciais de 2018 e a avaliação do novo mandato presidencial de Nicolás Maduro (2019-2025) como "ilegítimo" (ITAMARATY, 2019c), várias medidas foram tomadas em relação às relações diplomáticas com a Venezuela. Dentre elas, uma das mais importantes é que, depois da

\footnotetext{
${ }^{15}$ Se trata de uma doutrina criada em 1930 pelo então Secretário de Relações Exteriores Genaro Estrada que defende a livre autodeterminação dos povos e a não ingerência nos assuntos internos de outros países como elementos centrais da diplomacia mexicana. Esta doutrina, consagrada na Constituição mexicana (art. 89, inciso X), orientou a política externa do país ao longo da maior parte do século XX e está sendo novamente utilizada de forma central pela diplomacia do governo de Andrés Manuel López Obrador (SMITH, 2019).

16 A Venezuela já tinha sido suspendida em dezembro de 2016 por incumprir alguns compromissos que adquiriu após seu ingresso como membro pleno do bloco em 2012. Contudo, a suspensão da Venezuela por tempo indefinido foi uma decisão tomada em 2017, como resultado da aplicação do Protocolo de Ushuaia sobre Compromiso Democrático no Mercosul.
} 
Revista Brasileira de História \& Ciências Sociais - RBHCS

Vol. 13 No 26, Janeiro - Junho de 2021

autoproclamação de Juan Guaidó como presidente, 11 países do Grupo ${ }^{17}$ assinaram a Declaração de Ottawa (ITAMARATY, 2019d) na qual reconhecem a Juan Guaidó como presidente encarregado da República Bolivariana da Venezuela e seu governo como "legítimo", de acordo com as normas constitucionais e dada a "ilegitimidade" do regime de Nicolás Maduro. Neste documento, são reconhecidos também os representantes do governo de Guaidó e é feito um apelo à comunidade internacional para aumentar o reconhecimento da sua figura e apoiar sua luta e a da Assembleia Nacional a favor do estabelecimento de um governo de transição democrática.

Um ponto de inflexão que este documento estabelece na diplomacia do Grupo de Lima é que, a partir deste momento, são rejeitadas as iniciativas de diálogo com o governo de Maduro. A este respeito, se considera que tais iniciativas foram "manipuladas pelo regime" e transformadas em "manobras ditatoriais para se perpetuar no poder" (ITAMARATY, 2019d). Finalmente, entre as diversas medidas adotadas, é feito um apelo a favor da convocação de eleições "livres e justas, convocadas pelas autoridades legítimas"; uma convocação da Força Armada Nacional da Venezuela para que manifeste a sua lealdade perante o Presidente Encarregado Juan Guaidó a partir das disposições constitucionais; e um "apelo aos membros da comunidade internacional para impedir o regime de Maduro de realizar transações financeiras e comerciais no exterior, ter acesso aos ativos internacionais da Venezuela e ser capaz de fazer negócios em petróleo, ouro ou outros ativos” (ITAMARATY, 2019d).

Desde o estabelecimento da distinção entre "governo legítimo" e "governo ilegítimo", as iniciativas do Grupo de Lima têm assumido um tom parcial e de aberta oposição ao governo de Nicolás Maduro, definindo-o como autoritário, ditatorial e caracterizado por sistemáticas violações aos direitos humanos e atividades ilícitas de lavagem de dinheiro, corrupção, tráfico de drogas e terrorismo (ITAMARATY, 2018b, 2018d, 2018f, 2019a, 2019c, 2019d, 2019g, 2019h, 2019j, 2019o, 2019r, 2019s, 2019u, 2020h, 2020s). De forma paralela, os países que compõem este agrupamento têm feito pressão diplomática e promovido o isolamento do governo venezuelano fazendo, por exemplo, diversos apelos para fomentar a cooperação e a convergência com

${ }_{17}$ Argentina, Brasil, Canadá, Chile, Colômbia, Costa Rica, Guatemala, Honduras, Panamá, Paraguai e Perú. 
organismos internacionais e foros que discutem a situação venezuelana como a ONU ou o GCI. Além disso, têm defendido o ingresso de ajuda humanitária para a população venezuelana e o uso de sanções políticas e econômicas, exortando também os países que ainda mantém relações com o governo Venezuelano, como China e Rússia, a apoiar a transição democrática (ITAMARATY, 2018, 2019h, 2019l, 2019u, 2020b).

Em oposição às tradições regionais das últimas décadas de resolução pacífica das controvérsias fora do âmbito da OEA e, portanto, às margens da política estado-unidense, o Grupo de Lima tem considerado também a situação venezuelana como uma "ameaça à paz e a segurança internacionais, com efeitos regionais e globais" (ITAMARATY, 2019h). Como consequência, apesar de que os países integrantes do bloco "rejeitam qualquer ameaça ou ação que implique uma intervenção militar na Venezuela e condenam a ingerência estrangeira no país" (ITAMARATY, 2019h), ao passo que "reiteram seu apoio a uma solução política, pacífica, democrática e liderada pelos próprios venezuelanos" (ITAMARATY, 2019u), afirmam também que "manter o status quo na Venezuela não é uma opção" (ITAMARATY, 2019u). Assim, a maioria dos Estados-Parte convocou a reunião do órgão de consulta do Tratado Interamericano de Assistência Recíproca (TIAR) ${ }^{18} \mathrm{e}$ votou a favor da sua ativação (OEA, 2019b). ${ }^{19}$ Esta aprovação, ocorreu mediante a Resolução de 23 de setembro de 2019 (OEA, 2019c) que considera que a República Bolivariana da Venezuela "representa uma ameaça para a manutenção da paz e da segurança no continente, nos termos do artigo 6 do TIAR ${ }^{20}$. A ativação deste

18 O TIAR é um tratado de defesa hemisférica que garante assistência mútua perante agressões externas. Criado em 1947 no contexto do início da Guerra Fria, o TIAR estabelece que "um ataque armado por qualquer Estado contra um Estado americano será considerado como um ataque contra todos os Estados americanos" e define as responsabilidades e protocolos de ação em caso de que este fenômeno se verifique (OEA, 2019a). Apesar de ter sido invocado diversas vezes, a sua aplicação real nunca se concretizou pelo contexto de ameaça de um conflito a escala global e serviu, sobretudo, para consolidar a América Latina como área de influência dos Estados Unidos. Mais recentemente, a sua invocação durante a Guerra das Malvinas (1982), na qual os Estados Unidos se posicionaram a favor da Inglaterra, fez com que o TIAR perdesse sua legitimidade como mecanismo de segurança e defesa americana. No caso da Venezuela, o país se retirou do TIAR em 2013, mas a Assembleia Nacional, liderada por Juan Guaidó, aprovou por unanimidade seu retorno em julho de 2019.

${ }^{19}$ A decisão de resolução CP/RES. 1137 (2245/19) foi aprovada com 12 votos a favor (Venezuela, Argentina, Brasil, Chile, Colômbia, El Salvador, Estados Unidos, Guatemala, Haiti, Honduras, Paraguai, República Dominicana), 5 abstenções (Trinidad e Tobago, Uruguai, Costa Rica, Panamá, Peru) e 1 ausente (Bahamas).

${ }_{20} \mathrm{O}$ artigo especifica que o TIAR pode ser ativado "se a inviolabilidade ou integridade do território ou a soberania ou independência política de qualquer Estado americano forem 
instrumento não está isenta de polêmicas e foi denunciada por Uruguai, por considerar que abre o caminho para uma intervenção armada na Venezuela.

Mais recentemente, o Grupo de Lima tem condenado as agressões contra Juan Guaidó (ITAMARATY, 2020d) e promovido investigações contra funcionários do governo de Maduro, envolvidos em processos de violações de direitos humanos e atividades ilícitas como lavagem de ativos, tráfico de drogas, terrorismo e seu financiamento. Além disso, o Grupo de Lima tem visibilizado a crise venezuelana a nível internacional e denunciado reiteradamente o governo de Maduro por sistemáticas violações aos direitos humanos. Ao mesmo tempo, com a ajuda dos Estados Unidos, tem exercido pressão e buscado o apoio de organismos internacionais para aumentar o isolamento diplomático de Maduro; levando o caso do país sul-americano ao Conselho de Segurança e o Conselho de Direitos Humanos das Nações Unidas, além de buscar ações de coerção mediante, por exemplo, a denúncia do governo na Corte Penal Internacional (CPI) por crimes de lesa humanidade (ITAMARATY, 2018b, 2019a, 2019e, 2019h, 2019s, 2019u, 202ob, 2020c, 2020h).

Embora o Grupo de Lima seja um foro de diálogo que busca a restauração da democracia venezuelana através de uma saída pacífica e negociada, e não tenha como prioridade a abordagem da questão migratória, este fenômeno tem sido objeto de diversas reuniões, assim como de declarações, comunicados e notas. Algumas das ações mais relevantes respeito ao êxodo venezuelano, têm sido a sua definição como um fenômeno "massivo", "com nuances trágicas pela expulsão forçada de pessoas", "sem precedentes" e "de caráter principalmente intrarregional", que constitui "uma das maiores crises humanitárias a nível global" e é "provocado por uma crise multidimensional sem precedentes" que implica uma crise humanitária, política, econômica, social, ambiental e moral e está intimamente vinculado com a ruptura da ordem constitucional no país; o reconhecimento dos países latino-americanos como territórios de trânsito e destino destes deslocamentos e dos múltiplos desafios que o êxodo venezuelano implica no âmbito da saúde, educação, nutrição e integração das pessoas

afetados por uma agressão que não seja um ataque armado, ou por um conflito extracontinental ou intracontinental, ou por qualquer outro fato ou situação que possa colocar a paz da América em perigo, o Órgão de Consulta reunir-se-á imediatamente, a fim de acordar as medidas que, em caso de agressão, devam ser tomadas em socorro ao agredido ou em qualquer caso as que devam ser tomadas para a defesa comum e para a manutenção da paz e a segurança do continente" (OEA, 2019a). 
migrantes; a convocação de reuniões de alto nível com autoridades responsáveis pelas migrações e o refúgio para intercambiar experiências e definir as diretrizes para gerar uma resposta integral, incluindo questões relativas à oferta de facilidades migratórias e documentos de identidade; e a discussão de medidas para facilitar a permanência e o trânsito de migrantes (ITAMARATY, 2017b, 2017f, 2018a, 2018e, 2018f, 2019a, 2019d, 2019h, 2019j, 2019l, 2019o, 2019r, 2019s, 2019u, 2020b, 2020g).

Outros pontos chave da ação do Grupo de Lima têm sido: o apelo para aumentar e fortalecer a cooperação internacional e o apoio, especialmente financeiro para ajudar a migração venezuelana e os países de acolhida, de modo que estas nações fortaleçam sua capacidade de atendimento e resposta humanitária; o apelo para que o acolhimento e a assistência oferecida aos migrantes venezuelanos não sejam politizados; o apelo a Venezuela para que estabeleça um sistema de intercâmbio de informações epidemiológicas com os países vizinhos com o objetivo de coordenar esforços na contenção de doenças, sobretudo nas áreas de fronteira; a convocação de uma reunião de alto nível com autoridades sanitárias para coordenar ações em matéria de saúde pública e fortalecer a cooperação para atender a emergência epidemiológica; o registro regional de testemunhas de migrantes e refugiados venezuelanos sobre violações dos direitos humanos com o fim de apresentar à comunidade internacional a gravidade da situação no país; e o apoio a iniciativas internacionais como a Conferência Internacional de Solidariedade sobre a Crise de Refugiados e Migrantes de Venezuela e a iniciativas regionais de coordenação como o Processo de Quito (ITAMARATY, 2017b, 2017f, 2018e, 2018f, 2019a, 2019d, 2019h, 2019m, 2019o, 2019s, 202ob, 2020g).

A partir dos compromissos adquiridos no Grupo de Lima, o Processo de Quito surgiu na capital equatoriana, com a Declaração de Quito, assinada no dia 4 de setembro de 2018. ${ }^{21}$ De forma semelhante ao Grupo de Lima, este processo foi criado por iniciativa presidencial, com o apoio de instituições especializadas no tratamento do fenômeno migratório como a OIM e o ACNUR. Neste caso, é resultado da proposta do presidente equatoriano Lenín Moreno e forma parte da sua política externa em relação à Venezuela que, a diferença da gestão do seu

${ }^{21} \mathrm{O}$ documento foi assinado por 11 dos 13 países participantes: Argentina, Brasil, Chile, Colômbia, Costa Rica, Equador, México, Panamá, Paraguai, Peru e Uruguai. Em contrapartida, Bolívia e República Dominicana se abstiveram de assinar o acordo. 
antecessor Rafael Correa, implica relações tensas ${ }^{22}$ com o governo de Nicolás Maduro, a denúncia da crise multidimensional da Venezuela e sua ativa participação no Grupo de Lima. Segundo o portal institucional do grupo, este é definido oficialmente como uma "iniciativa intergovernamental técnica e regional que foi estabelecida para estabelecer mecanismos e compromissos não obrigatórios entre os países latino-americanos e caribenhos para coordenar respostas perante a crise de mobilidade humana dos cidadãos venezuelanos" (PQ, 2021).

Assim como no caso peruano, a iniciativa equatoriana não é casual, pois o Equador constitui atualmente o quarto principal país receptor do fluxo venezuelano em termos regionais e um importante território de trânsito para a população que se desloca até países como Perú e Chile (R4V, 2021). A diferença do Grupo de Lima que possui objetivos mais abrangentes que visam contribuir à resolução da crise política venezuelana, o Processo de Quito tem um caráter prevalentemente técnico e circunscrito à gestão e cooperação regional respeito à migração venezuelana. Esta característica fica evidente na Primeira Declaração do Processo de Quito (PQ) que diz que o grupo tem o objetivo de "trocar informações e boas práticas com vistas a articular a coordenação regional em relação à crise migratória dos cidadãos venezuelanos na região" (PQ, 2018a).

Como podemos observar na tabela seguinte, na primeira Declaração do Processo de Quito, os Estados signatários se comprometeram a intercambiar informação em matéria migratória e a implementar políticas públicas com enfoque de direitos humanos na acolhida do êxodo venezuelano, ao passo que, entre outros assuntos, fizeram um apelo para aumentar a cooperação internacional técnica e financeira (Tabela 3).

\footnotetext{
${ }^{22}$ A postura do governo de Lenín Moreno em relação à situação da Venezuela pode ser dividida em duas fases. Um primeiro momento caracterizado pela gestão da chanceler María Fernanda Espinosa em que o governo evitou se pronunciar em contra de Nicolás Maduro. Após a saída da chanceler, a postura da diplomacia equatoriana mudou completamente ao ponto que um dos momentos mais tensos entre as duas nações ocorreu em 18 de outubro de 2018. Nesta data, o governo equatoriano expulsou a embaixadora venezuelana, Carol Delegado, que estava em missão diplomática em Quito desde novembro de 2014, e a Venezuela fez o mesmo com a Encarregada de Negócios equatoriana em Caracas, Elizabeth Méndez (GONZÁLEZ, 2019). Após este episódio, o governo equatoriano não enviou representantes para a cerimônia de posse de Nicolás Maduro em 2019 e, como parte do Grupo de Lima, tem adotado uma postura de aberta oposição ao seu governo.
} 


\section{Revista Brasileira de História \& Ciências Sociais - RBHCS Vol. 13 No 26, Janeiro - Junho de 2021}

\section{Tabela 3. Principais pontos* da Declaração de Quito (2018)}

\begin{abstract}
-Destacar os esforços dos governos regionais na recepção de cidadãos venezuelanos em situação de mobilidade humana, especialmente aqueles em condições vulneráveis.

-Declaração da intenção de trabalhar de forma individual e cooperativa na prestação de assistência humanitária e em temas como acesso à documentação e permanência regular; combate ao tráfico de pessoas e contrabando de migrantes; combate à violência sexual e de gênero; proteção infantil; rejeição de discriminação e xenofobia; acesso a procedimentos para determinar o status de refugiado e, em geral, na implementação de políticas públicas destinadas a proteger os direitos humanos de todos os migrantes.
\end{abstract}

-Reconhecer a importância da cooperação técnica e financeira fornecida pelos Estados cooperantes e/ou organizações internacionais especializadas para abordar a crescente migração venezuelana.

-Instar o Governo da República Bolivariana da Venezuela a tomar as medidas necessárias para fornecer a seus cidadãos documentos de identidade e de viagem com o fim de evitar a migração irregular e facilitar sua inserção e acesso à direitos nos países de destino.

- Aceitar documentos de viagem vencidos como documentos de identidade de cidadãos venezuelanos para fins de migração e estabelecer um programa regional, com o apoio do Sistema das Nações Unidas, particularmente da OIM, para o intercâmbio de informações relevantes sobre os migrantes venezuelanos.

-Prever que os Estados da região coordenem esforços através de organizações como a OEA, a OIM e outras para combater o tráfico de pessoas e o contrabando de migrantes.

-Ratificar o compromisso dos Estados da região, de acordo com a disponibilidade de recursos, leis internas e as possibilidades de cada país anfitrião, de proporcionar aos migrantes venezuelanos o acesso aos serviços públicos de saúde, educação, oportunidades no mercado de trabalho e acesso aos sistemas de justiça.
-Reconhecer que a migração pendular e de trânsito requer apoio e cooperação regional para fortalecer as medidas de países fronteiriços como a Colômbia, bem como para o Equador e o Peru, dado que gera um corredor migratório para esses dois países.

- Ratificar os compromissos dos Estados da região com relação à luta coordenada contra a discriminação, a intolerância e a xenofobia e implementar, na medida do possível para cada país, iniciativas e esforços estatais, individualmente e/ou em conjunto. Neste sentido, reiterar sua preocupação com a grave deterioração da situação interna causada pela migração massiva de venezuelanos e solicitar a abertura de um mecanismo de assistência humanitária.

-Os Estados concordam em cooperar mutuamente para ajudar seus cidadãos e instam o Governo da República Bolivariana da Venezuela a aceitar a cooperação dos governos da região e das organizações internacionais, a fim de enfrentar a situação de suas respectivas comunidades estabelecidas na Venezuela.

-Reforçar o papel da Comunidade Andina e do Mercosul para enfrentar, de forma abrangente e coordenada, o fluxo maciço de cidadãos venezuelanos e tomar medidas imediatas para enfrentar esta crise migratória humanitária. Da mesma forma, nas esferas da Conferência Regional sobre Migrações e da Conferência Sul-Americana sobre Migrações.

Elaboração própria a partir da síntese da Declaração Original (PQ, 2018a).

*O documento original contém 18 pontos: um deles se refere à organização do segundo encontro do Processo de Quito e os dois pontos finais são de agradecimentos à participação dos presentes e ao Equador pela organização da iniciativa.

O Processo de Quito está formado atualmente por 14 países (Argentina, Bolívia, Brasil, Colômbia, Chile, Costa Rica, Guiana, Equador, Mexico, Panamá, 
Paraguai, Peru, República Dominicana e Uruguai) e, no período 2018-2020, tem emitido seis declarações oficiais, resultado dos encontros ou rodadas. ${ }^{23} \mathrm{O}$ Processo conta também com um Grupo de Amigos que nasceu a partir dos acordos alcançados durante a V Rodada do Processo de Quito (PQ, 2019b). O grupo, formalmente constituído na VI Rodada (PQ, 2020), está atualmente composto por Alemanha, Canadá, Espanha, Estados Unidos, França, Itália, Países Baixos, Reino Unido, Suíça e União Europeia. Alguns dos principais propósitos deste agrupamento são visibilizar a migração venezuelana a nível extrarregional e fazer que o fenômeno se torne uma prioridade da agenda internacional, assim como aumentar a solidariedade e a cooperação internacional, especialmente técnica e financeira (PQ, 2018a, 2018b, 2019a, 2019b, 2019c, 2020).

A partir dos compromissos assumidos na primeira reunião, no segundo encontro do Processo de Quito, também celebrado na capital andina em novembro de 2018, foi aprovada a segunda declaração que estabelece um Plano de Ação que se caracteriza por três enfoques: a) regularização da situação migratória dos venezuelanos na região; b) cooperação regional com a Venezuela; e c) cooperação internacional com organismos internacionais como a OIM e a OEA, Processos Consultivos Regionais sobre Migração como a CRM e CSM e processos de integração regional como o Mercosul, a CAN e a Unasul (PQ, 2018a, 2018b, 2019a, 2019b, 2019c, 2020). Como resultado deste Plano de Ação e dos compromissos assumidos nas reuniões sucessivas, também conhecidas como capítulos de Buenos Aires, Bogotá e Santiago (PQ, 2019b, 2019c, 2020), foram estabelecidas nove áreas de trabalho que contam com países líderes ou responsáveis pelo seu desenvolvimento e dispõem de apoio técnico específico por parte das diversas agências especializadas das Nações Unidas (Tabela 4).

\footnotetext{
23 Além dos encontros oficiais, cabe destacar também as inúmeras reuniões internas de trabalho entre as equipes técnicas, pontos focais de cada país, Presidência Pró-Tempore e Secretaria Técnica, assim como as reuniões de autoridades consulares e chanceleres dos países membros e aquelas organizadas junto aos representantes do Grupo de Amigos do Processo de Quito.
} 
Tabela 4. Áreas de trabalho, países líderes e apoio técnico por área no Processo de Quito

\begin{tabular}{|c|c|c|}
\hline Área de trabalho & Países líderes & Apoio Técnico \\
\hline Asilo & Brasil & ACNUR \\
\hline Centros de orientação & Brasil & OIM \\
\hline Covid-19 & Peru & $\begin{array}{c}\text { Organização } \\
\text { Panamericana da Saúde } \\
\text { (OPS) }\end{array}$ \\
\hline Educação & Argentina & $\begin{array}{c}\text { Organização das Nações } \\
\text { Unidas para a Edução, a } \\
\text { Ciência e a Cultura } \\
\text { (UNESCO) }\end{array}$ \\
\hline Inserção socioeconômica & & $\begin{array}{c}\text { Organização Internacional } \\
\text { do Trabalho (OIT) e } \\
\text { Programa de } \\
\text { Desenvolvimento das } \\
\text { Nações Unidas (PNUD) }\end{array}$ \\
\hline Proteção de crianças e & & $\begin{array}{c}\text { Fundo das Nações Unidas } \\
\text { para a Infância (UNICEF) } \\
\text { adolescentes }\end{array}$ \\
\hline Reunificação familiar & Colômbia & OIM, ACNUR \\
\hline Tráfico humano & Chile & Programa Conjunto das \\
HIV-SIDA & Chile e Equador & Unidas sobre \\
& Argentina & \\
\hline
\end{tabular}

Elaboração própria a partir das informações disponíveis no site oficial do Processo de Quito $(\mathrm{PQ}, 2021)$.

Apesar de ser uma iniciativa ad hoc, a diferença do Grupo de Lima, o Processo de Quito tem um certo nível de institucionalidade e uma estrutura mais definida. Além de ter nove áreas de trabalho claramente identificadas, conta com uma Presidência Pró-Tempore, uma Secretaria Técnica e uma equipe permanente, assim como com um portal institucional que reúne todas as informações relativas a este processo. A primeira é ocupada de forma rotativa por cada Estado Parte e, no período 2018-2020, tem sido responsabilidade do Equador, Argentina, Colômbia e Chile, dando lugar aos diversos capítulos do processo: Quito, Buenos Aires, Bogotá e Santiago. Já a Secretaria Técnica, coordenada pela OIM e pelo ACNUR, é o órgão de assessoria técnica que coordena, prepara e executa os assuntos do Processo de Quito. Através dela, os organismos internacionais que participam deste processo multilateral articulam seus trabalhos com a Presidência Pro Tempore e os discutem em oficinas técnicas temáticas, por meio da liderança dos países líderes ou responsáveis 
Revista Brasileira de História \& Ciências Sociais - RBHCS

Vol. 13 No 26, Janeiro - Junho de 2021

pelos temas. Os resultados deste processo são discutidos politicamente pela Presidência Pro Tempore e integrados às Declarações Conjuntas para avançar na elaboração de respostas comuns perante o êxodo venezuelano (PQ, 2021).

A equipe permanente do Processo de Quito está composta por um coordenador conjunto de ACNUR-OIM que trabalha dentro dos escritórios regionais do ACNUR-OIM no Panamá e um assessor técnico de comunicação, bem como um ponto focal para cada agência das Nações Unidas. De fato, o Processo conta com equipes técnicas de trabalho de várias agências internacionais, inicialmente lideradas pela OIM e o ACNUR, mas nas quais hoje participam também outras agências tais como a OIT, a UNICEF, a ONU-AIDS, a ONU-Mulheres, a OPS, o PNUD e a UNESCO. Estas equipes desenvolvem iniciativas regionais que podem ser implementadas pelos governos através dos respectivos ministérios de cada área e seus pontos focais (PQ, 2021). Por sua vez, a criação do portal institucional do Processo, foi resultado da Declaração do capítulo de Santiago (PQ, 2020) e tem o propósito de compartilhar as decisões do Processo e melhorar sua comunicação. Ao mesmo tempo, pretende unificar toda a documentação relevante sobre o mesmo e gerar um espaço de interação entre Estados, organismos técnicos e sociedade civil, além de divulgar informação atualizada sobre a "crise migratória e humanitária venezuelana na região".

Um ponto central do discurso do Processo de Quito é que o êxodo venezuelano é analisado a partir da perspectiva da mobilidade humana, considerando os diversos fenômenos que esta implica, tais como o imigração, o refúgio, a emigração, o trânsito e o tráfico e contrabando de pessoas. A migração é definida em termos de "crise migratória e humanitária", resultado das dificuldades que atravessa a Venezuela e formada de maneira significativa por coletivos de alta vulnerabilidade como crianças e adolescentes, pessoas da terceira idade, indígenas e pessoas com deficiência ou com graves problemas de saúde (PQ, 2018a, 2018b, 2019a, 2019b, 2019c, 2020).

Embora, como dito acima, o Processo de Quito tenha objetivos de caráter técnico e circunscritos à cooperação em matéria migratória, desde o capítulo de Buenos Aires (PQ, 2019b), o discurso do Processo de Quito converge com o do Grupo de Lima em relação à avaliação da situação venezuelana e as implicações da crise do país andino em termos intra e extrarregionais. Assim, os Estados 
Parte têm manifestado "sua preocupação pela grave crise política que atravessa a Venezuela, com efeitos negativos sobre o plano migratório, humanitário, econômico e social, o que constituiu uma ameaça à paz e a segurança regional e internacional" e têm invocado também a abertura de um "mecanismo de assistência humanitária” no país (PQ, 2018a, 2019b). Contudo, a diferença do Grupo de Lima que, desde o reconhecimento do governo de Juan Guaidó tem assumido um caráter parcial e de aberta oposição ao atual governo venezuelano, os países do Processo de Quito têm feito um apelo "a todos os atores da comunidade internacional para que se comprometam e apoiem um pronto restabelecimento da ordem institucional na Venezuela, através de uma solução política, pacífica e democrática, conduzida pelos próprios venezuelanos" (PQ, 2019b).

No que se refere especificamente às migrações, três são os enfoques predominantes na abordagem do Processo de Quito: segurança e controle, direitos humanos e migração e desenvolvimento. Embora as três perspectivas estejam interrelacionadas e alinhadas com o sistema de governança global das migrações promovido pelas Nações Unidas, podemos distinguir algumas ações nas quais prevalece um ou outro enfoque. A perspectiva de segurança e controle invoca, por exemplo, as premissas do Pacto Mundial da Migração sobre a necessidade de promover uma "migração segura, ordenada e regular". Para tanto, promove medidas como: o intercâmbio de informações sobre migrantes entre os países da região e a cooperação nas áreas de fronteira; a criação de documentos migratórios específicos como a Tarjeta de Movilidad Migratoria (TIM) e a melhoria dos registros biográficos e biométricos dos migrantes e solicitantes de refúgio; a harmonização e coordenação de políticas migratórias entre os Estados Parte; políticas de ação contra o tráfico e contrabando de migrantes; fortalecimento de instituições migratórias nacionais como as Comissões Nacionais para Refugiados (CONARES); e a criação de medidas de acompanhamento e facilitação do "retorno voluntario" (PQ, 2018a, 2019b, 2019c).

Em segundo lugar, o enfoque de direitos humanos invoca os acordos regionais e internacionais sobre direitos humanos e está presente nas diversas áreas de trabalho do Processo de Quito. Entre outras ações, tem permitido: o reconhecimento de documentos de viagem vencidos, o intercâmbio de boas 
práticas e a promoção de medidas de regularização e reunificação familiar; a criação de pontos de orientação e assistência para migrantes e solicitantes de refúgio; a denúncia e criação de medidas para combater a discriminação e a xenofobia; e a criação, em parceria com organismos como o PNUD, a UNESCO, a UNICEF, a OPS e a ONU-AIDS, de medidas de assistência e proteção em áreas como a saúde, educação e nutrição de crianças e adolescentes, assim como de coletivos como as pessoas da terceira idade, a população indígena ou pessoas com graves problemas de saúde. Além disso, uma diferença importante do Processo de Quito em relação ao Grupo de Lima é que, na hora de abordar o fenômeno migratório, considera também a emigração e prevê diversas medidas de cooperação para fornecer assistência aos nacionais de países como Colômbia, Equador ou Argentina que, em diversos níveis, contam com significativos coletivos de emigrantes residentes na Venezuela (PQ, 2018a, 2019b, 2019c).

Em terceiro lugar, no que diz respeito às medidas influenciadas pela perspectiva de migração e desenvolvimento, podemos destacar: a promoção de medidas de revalidação de diplomas; o intercâmbio de informações entre os serviços públicos de emprego dos Estados Parte; o desenho de projetos de integração laboral o reconhecimento de competências técnicas e a criação de uma Estratégia Regional de Integração Socioeconômica (PQ, 2018a, 2018b, 2019 a 2019b, 2019c, 2020). No contexto da Covid-19, este e os precedentes enfoques contam uma área de trabalho específica sobre a pandemia que visa oferecer informações e propostas em relação às problemáticas que afetam especificamente os migrantes venezuelanos ( $P Q, 2020)$.

Apesar de que, como visto, a questão migratória tem um peso diferenciado no Processo de Quito, respeito ao Grupo de Lima, ambos mecanismos ad hoc têm sido centrais para visibilizar o êxodo venezuelano como consequência da crise multidimensional que atravessa o país sul-americano. Embora se trate de um fenômeno global, estes espaços têm evidenciado também que o êxodo venezuelano tem caráter majoritariamente regional e possui demandas que superam as capacidades autônomas dos países latino-americanos e caribenhos. Como consequência, a cooperação promovida com organismos internacionais e países intra e extrarregionais e o apelo para aumentar a cooperação técnica e financeira, têm sido dois dos objetivos centrais destes processos. Contudo, a migração venezuelana continua sendo um dos fenômenos 
menos financiados pela comunidade internacional e, apesar de se tratar de fenômenos semelhantes, a migração síria $(\$ 3,150)$ recebeu dez vezes mais recursos que a migração venezuelana (\$265) no período 2016-2020 (BAHAR; DOOLEY, 2021). Além disso, até março de 2021, os fundos internacionais destinados à migração venezuelana $(\$ 22,919,871)$ correspondem apenas ao $2 \%$ dos recursos requeridos pelo Plano de Resposta para Refugiados e Migrantes da Venezuela (RMRP) $(\$ 1,416,314,539)$ (R4V, 2021).

Por último, cabe destacar que a chegada da pandemia de Covid-19 tem provocado uma diminuição da saída de venezuelanos e inclusive diversos processos de retorno (OEA, 2020), mas o êxodo de pessoas provenientes deste país continua e aumentará na medida em que as fronteiras sejam reabertas e a crise multidimensional que afeta o país andino se agrave. A este respeito, embora o Grupo de Lima e o Processo de Quito tenham obtido importantes avanços, sobretudo na visibilização da situação venezuelana e na promoção da cooperação multilateral, não tem conseguido cumprir com dois dos seus objetivos primários: encontrar uma saída pacífica ao conflito venezuelano e aumentar a captação de fundos para melhorar a assistência humanitária e promover a integração dos cidadãos venezuelanos.

\section{Conclusões}

Como vimos ao longo deste trabalho, os países da América Latina historicamente contribuíram ao desenvolvimento do multilateralismo e fomentaram diversas iniciativas deste tipo a nível regional e extrarregional. Porém, desde 2016, a região experimenta uma crise do multilateralismo e fenômenos como a fragmentação política e o "multilateralismo contestado" têm colocado em discussão os espaços tradicionais para a resolução de crises regionais, como a OEA e, mais recentemente a Unasul. Estes fenômenos têm afetado também o tratamento das migrações internacionais, abordadas em anos recentes a partir de processos como a Conferência Sul-americana de Migrações. Tal cenário acontece de forma paralela ao agravamento da situação na Venezuela que, mesmo não sendo um país em guerra e tendo as maiores reservas petroleiras do mundo, hoje enfrenta a pior crise da sua história e um êxodo de população sem precedentes na região. Como resultado, é nos 
mecanismos de cooperação ad hoc como o Grupo de Lima e o Processo de Quito que estes desafios têm sido tratados de forma prevalente.

Ambos os processos são decorrentes da iniciativa presidencial do Peru e do Equador e constituem instrumentos da política externa dos Estados Parte. Enquanto mecanismos ad hoc, estes processos têm natureza não vinculante, temporária, excepcional e baixa (Processo de Quito) ou nula institucionalização (Grupo de Lima). Estas características determinam que tenham ampla flexibilidade e capacidade de rápida atuação, mas também divisões e importantes transformações na sua postura à medida que muda o cenário político dos países da região. Além disso, embora tenham objetivos diferenciados e concedam diversos graus de centralidade à questão migratória, ambos os espaços têm sido fundamentais para visibilizar o êxodo venezuelano a nível global, ao passo que facilitaram o intercâmbio de informação e boas práticas, permitindo também o desenho de estratégias regionais e políticas públicas perante os desafios da migração.

Desde a sua fundação, a contribuição destes espaços é inegável, mas cabe destacar que o que prevalece é a desarticulação das respostas perante o êxodo venezuelano e o forte distanciamento entre discursos e práticas. Com efeito, como mostram a aplicação da definição ampliada de refugiado estabelecida pela Declaração de Cartagena e o recente reconhecimento facilitado prima facie do refúgio no caso brasileiro, ou a criação de um Estatuto de Proteção Temporal por parte do Estado colombiano, a variável ideológica jogou e ainda joga a favor da migração venezuelana. Entretanto, em oposição às narrativas sobre a criação de políticas migratórias com enfoque de direitos humanos, em diversos dos países que conformam o Grupo de Lima e o Processo de Quito como Equador, Peru, Chile e Brasil, há retrocessos importantes em relação à livre mobilidade e crescentes formas de militarização, securitização e criminalização das migrações. Igualmente, apesar dos esforços e os reiterados apelos à comunidade internacional do Grupo de Lima e do Processo de Quito, o apoio financeiro aos países da região ainda não é uma prioridade e os recursos para o êxodo venezuelano continuam sendo muito inferiores aos destinados para atender crises semelhantes como a síria.

Por outro lado, a diferença dos espaços multilaterais tradicionais na região, o Processo de Quito e, especialmente, o Grupo de Lima, romperam 
Revista Brasileira de História \& Ciências Sociais - RBHCS

Vol. 13 No 26, Janeiro - Junho de 2021

tradições de respeito à soberania e não interferência nos assuntos internos de outros países, assim como protocolos de atuação nas crises latino-americanas, chegando inclusive a considerar a situação venezuelana como uma ameaça. Como consequência, os Estados Parte têm aplicado sanções e implementado ações de isolamento contra o governo venezuelano que incluíram a ativação do TIAR. Neste processo, a diferença da postura de autonomia e rejeição da interferência norte-americana que caracterizou a atuação dos países da região em décadas precedentes, o papel dos Estados Unidos tem sido central. Porém, numa conjuntura de alta politização e fortalecimento dos governos de esquerda, o discurso comum e o alcance de consensos regionais diminuem e, portanto, a ação destes mecanismos de cooperação se enfraquece. A título ilustrativo podemos destacar que vários países como México ou Argentina têm abandonado o Grupo de Lima, enquanto apelam para uma solução pacífica e negociada da crise venezuelana.

Por fim, a partir da análise comparada do Grupo de Lima e do Processo de Quito podemos destacar que inovar em termos de diálogo e cooperação multilateral pode ser uma vantagem, mas valorizar a experiência é essencial. A este respeito, é necessária a recuperação dos espaços tradicionais de abordagem de crises e de fenômenos globais como as migrações, assim como dos avanços alcançados nestas esferas. A migração venezuelana constitui um desafio regional sem precedentes que requer respostas urgentes e integrais. Tais respostas podem e devem apresentar inovações, mas é fundamental que recuperem também o legado destes espaços como as propostas de cidadania regional e as políticas baseadas em uma perspectiva real de direitos humanos. Da mesma forma, é evidente que o tratamento da migração é indissociável da busca por uma solução pacífica e negociada para a crise venezuelana, mas é preciso diferenciar as respostas dadas à migração da postura que cada país assume em relação ao governo venezuelano. Com independência do posicionamento político, os migrantes venezuelanos têm direito a uma vida e a um futuro melhores e os países latino-americanos têm uma oportunidade histórica de mostrar sua solidariedade regional e garantir que estes direitos se cumpram. 
Revista Brasileira de História \& Ciências Sociais - RBHCS

Vol. 13 No 26, Janeiro - Junho de 2021

\section{Referências}

ACNUR (Alto Comisariado de las Naciones Unidas para los Refugiados). Tendencias globales. Desplazamiento forzado en 2019. ACNUR, 2020. ACOSTA, Diego; BLOUIN, Cécile; FELINE, Luisa. La emigración venezolana: respuestas latinoamericanas. Fundación Carolina. Documentos de Trabajo, n. 3, 2019.

ADAMSON, F., \& TSOURAPAS, G. Migration diplomacy in world politics. International Studies Perspectives, 2019, 20(2).

BAENINGER, Rosana; JAROCHINSKI, João (coords.). Migrações venezuelanas. Campinas. Núcleo de Estudos Elza Berquió. 2018.

BAHAR, Dany; DOOLEY, Meagan. Venezuelan refugees and their receiving communities need funding, not sympathy. Brookings Institute, February 2021. Disponível em: $\quad$ https://www.brookings.edu/blog/upfront/2021/02/26/venezuelan-refugees-and-their-receiving-communitiesneed-funding-not-sympathy/Acesso em: 28/02/2021.

BARBIERI, Nicolás; RAMÍREZ, Jacques; OSPINA, María; PINCOWSCA, Bárbara; POLO, Sebastián. Respuestas de los países del Pacífico suramericano ante la migración venezolana: estudio comparado de políticas migratorias en Colombia, Ecuador y Perú. Diálogo Andino, n. 63, p.219-23, 2020.

BARDIN, Laurence. Análise de conteúdo. São Paulo: Edições 70, 2016.

BATALLAS, Cosme. Del grupo de Lima al proceso de Quito: análisis de las políticas públicas implementadas en el marco del multilateralismo sudamericano, como muestra de solidaridad y cooperación frente a la crisis migratoria venezolana. Lex: Revista de la Facultad de Derecho y Ciencia Política. Universidad Alas Peruanas, v. 18, n. 26, p. 415-440, 2020.

BBC. Cancilleres de 12 países de América y el Caribe suscriben en la "Declaración de Lima" que Venezuela "no es una democracia", 2017. Disponível em: https://www.bbc.com/mundo/40871449.amp Acesso em: 30/10/2020.

BETTS, Alexander (edit). "Introduction: Global Migration Governance", en BETTS, Alexander. Global Migration Governance. Oxford: Oxford University Press, 2011, pp. 1-33.

DOMENECH, Eduardo. Las políticas de migración en Sudamérica: elementos para el análisis crítico del control migratorio y fronterizo. Revista Terceiro Milênio, v. 8, n. 1, 2017, pp. 19-48. 
Revista Brasileira de História \& Ciências Sociais - RBHCS

Vol. 13 No 26, Janeiro - Junho de 2021

'Las migraciones son como el agua': Hacia la instauración políticas de 'control con rostro humano'. La gobernabilidad migratoria en la Argentina. Polis [En línea]. Revista Latinoamericana, n. 35, 2013.

ENCOVI (Encuesta Nacional de Condiciones de Vida) 2019-2020. Universidad Católica Andrés Bello, Caracas, 2020.

FERNANDES, Sandra; SIMÃO, Lucínia, Os conceitos e a evolução do multilateralismo: o nexo reflexão-ação. In, FERNANDES, Sandra; SIMÃO, Lucínia. O multilateralismo. Conceitos e práticas no século XXI, Coimbra: Universidade de Coimbra, 2019.

GANDINI, Luciana; PRIETO, Victoria; LOZANO, Fernando. El éxodo venezolano: migración en contexto de crisis y respuestas de los países latinoamericanos. In: GANDINI, Luciana; LOZANO, Fernando; PRIETO, Victoria. (coord). Crisis y migración de población venezolana. Entre la desprotección y la seguridad jurídica en Latinoamérica. México: Universidad Nacional Autónoma de México, 2019.

GARIP, Patricia. Latin America swings toward EU camp on Venezuela, 2021. Disponível em: https://www.argusmedia.com/en/news/2183300-latinamerica-swings-toward-eu-camp-on-venezuela Acesso em: 20/02/2021.

GRANJA, Lorena; VILLARREAL, María. MERCOSUR Migrante. Enfoques y evolución del tratamiento de la movilidad humana en el MERCOSUR. Revista Terceiro Milênio, v. 8, n. 1, 2017, pp. 49-78.

GRIFFITHS, Martin; O'CALLAGHAN, Terry. International Relations: The key concepts. London and New York: Routledge, 2002.

GONZÁLEZ, Mario. Ecuador y Venezuela amplían la distancia en relaciones diplomáticas. El Comercio. Disponível em: https://www.elcomercio.com/actualidad/ecuador-venezuela-diplomaciaposesion-maduro.html Acesso em: 30/03/2020.

LANDER, Edgardo. Notas sobre a implosão da Venezuela rentista. In: CORREA, José; UEMURA, Janaina; SIQUEIRA, Filomena. O Eclipse do progressismo. A esquerda latino-americana em debate. São Paulo: Editora Elefante, p. 233-240, 2018.

LANDMAN, Tood. Política comparada. Una introducción a su objeto y métodos de investigación. Madrid, Alianza Editorial, 2011. 
Revista Brasileira de História \& Ciências Sociais - RBHCS

Vol. 13 No 26, Janeiro - Junho de 2021

MÁRMORA, Lelio. Modelos de gobernabilidad migratoria. La perspectiva política en América del Sur. Revista Interdisciplinar da Mobilidade Humana (REMHU) v. 18, n. 35, 2010, pp. 71-92.

Conferencia Suramericana sobre Migraciones (CSM) 2010-2015. (2016), Buenos Aires: OIM.

MORSE, Julia; KEOHANE, Robert. "Contested multilateralism”, The Review of International Organizations, 9 (04), pp. 385-412, 2014.

NOLTE, Detlef. Lo bueno, lo malo, lo feo y lo necesario: pasado, presente y futuro del regionalismo latinoamericano. Revista Uruguaya de Ciencia Política, n. 28, v.1, p.131-156, 2019.

NEWMAN, Edward. A Crisis in Global Institutions? Multilateralism and International Security. Londres: Routledge, 2007.

Organización de Estados Americanos (OEA). Situación de los venezolanos que han retornado y buscan regresar a su país en el contexto del Covid-19. OEA, Septiembre, 2020.

OIM (Organização Internacional para as Migrações). Informe sobre las Migraciones en el Mundo 2019. Suiza: Organización Internacional para las Migraciones, 2020.

OIM. Regional Consultative Processes, 2021. Disponível em: https://www.iom.int/es/regional-consultative-processes-migration Acesso em: 15/12/2020.

PÁEZ, Tomás. La voz de la diáspora venezolana. Los libros de la Catarata, Madrid, 2015.

PÁEZ, Tomás; VIVAS, Leonardo. The Venezuelan Diaspora. Another Impeding crisis? Freedom House Report, April 2017.

KEOHANE, Robert. Multilateralism: an agenda of research. International Journal, XLV, 1990.

KOECHLIN, José; EGUREN, Joaquín. (edits.). El éxodo venezolano entre el exilio y la emigración. Colección OBIMID, v. 4, Lima/Madrid: OIM, Universidad Antonio Ruíz de Montoya, Fundación Konrad Adenauer, OBIMID, 2018.

RANA, Pradumma. Trade Multilateralism: Alive And Well Despite Trump. Eurasia Review. News and Analysis, 2020. Disponível em: 
Revista Brasileira de História \& Ciências Sociais - RBHCS

Vol. 13 No 26, Janeiro - Junho de 2021

https://www.eurasiareview.com/21072020-trade-multilateralism-alive-andwell-despite-trump-analysis/ Acesso em: 12/12/2020.

RIBEIRO HOFFMANN, Andreia. As organizações regionais e a promoção e proteção da democracia: reflexões a partir das práticas de intervenção democrática na América do Sul. Cadernos CRH (Online), v. 29, p. 47-57, 2016.

ROMERO, Carlos; LUJÀN, Carlos; TOKATLIAN, Juan; HIRST, Mónica. Geopolítica sudamericana del coronavirus. Nueva Sociedad, Sección Diálogo y Paz, abril, 2020.

ROJAS, Francisco. Rol y evaluación de la diplomacia de cumbres. Construyendo el multilateralismo cooperativo". In: ROJAS, Francisco (edit.) Multilateralismo: perspectivas latinoamericanas. Caracas, FLACSOChile, Editorial Nueva Sociedad, pp. 13-53, 2000.

RUGGIE, John. Multilateralism: the anatomy of an institution. International Organization, 46 (o3), pp. 561-598, 1992.

RÜLAND, Jürgen. The rise of "dimininished multilateralism": East Asian and European forum shopping in global governance». Asia Europe Journal, n. 9, p. 255-270, 2012.

SILVA, Pedro; DE SOUZA, Júlia. Fragmentação da Governança Regional: o Grupo de Lima e a política externa brasileira (2017-2019). Revista Mundo e Desenvolvimento, v. 2, n. 3, p. 6-39, 2029.

SMITH, Ricardo. Lecciones de Montevideo. Reevaluando la no intervención. Foreign Affairs Latinoamérica. Disponível em: https://revistafal.com/lecciones-de-montevideo-revaluando-la-nointervencion/ Acesso em: 14/12/2020.

TORREALBA, Ricardo; SUÁREZ, María; SCHLOETER, Mariluz. Ciento cincuenta años de políticas inmigratorias en Venezuela. Revista Estudios Demográficos y Urbanos, v. 17, n.3, p. 367-390, 1983.

VAL, Eduardo; SLOBODA, Pedro. Revisitando o novo multilateralismo latinoamericano e seu impacto na reforma do Conselho de Segurança das Nações Unidas. Revista VIA IURIS, n. 18, pp. 179-191, 2015.

VAN KLAVEREN, Alberto. El eterno retorno del regionalismo latinoamericano. Nueva Sociedad, n. 275, p. 62-72, 2018. La crisis del multilateralismo y América Latina. Análisis de

la Fundación Carolina, n.10, 2020. 
Revista Brasileira de História \& Ciências Sociais - RBHCS

Vol. 13 No 26, Janeiro - Junho de 2021

VILLARREAL, María. Regionalismos e migrações internacionais na América do Sul: contexto e perspectivas futuras sobre as experiências da Comunidade Andina, do Mercosul e da Unasul. Revista Espaço Aberto, v. 8, n.2, 2018, pp.131-148.

La cooperación regional ante la migración venezolana: el Grupo de Lima y el Proceso de Quito en perspectiva comparada. I Congreso Internacional de Movilidades Humanas Colombo-Venezolanas, Cúcuta, 2019a.

. O êxodo venezuelano: um desafio regional. Folha de São Paulo, 24/04/2019. 2019b. Disponível em:

https://www1.folha.uol.com.br/mundo/2019/04/o-exodo-venezuelano-umdesafio-regional.shtml Acesso em 12/05/2020. . Considerações sobre os vínculos entre migrações e política externa. Boletim NEAAPE, v. 3, p. 26-35, 2019c.

\section{Fontes primárias}

ITAMARATY. Declaração de Lima. 08 ago. 2017a.

Comunicado do Grupo de Lima sobre a usurpação das competências funcionais da Assembleia Nacional da Venezuela. 18 ago. 2017b.

. Declaração da segunda reunião do Grupo de Lima sobre a situação na Venezuela. 23 set. 2017c.

. Comunicado do Grupo de Lima sobre as eleições regionais na Venezuela. 05 out $2017 \mathrm{~d}$.

. Comunicado do Grupo de Lima sobre a realização das eleições regionais na Venezuela. 17 out. $2017 \mathrm{e}$.

. Declaração da terceira reunião do Grupo de Lima sobre a situação

na Venezuela. 26 out. $2017 f$.

. Comunicado do Grupo de Lima. 04 nov. 2017g.

IV Declaração do Grupo de Lima. 23 jan. 2018a.

Declaração do Grupo de Lima. 14 fev. 2018b.

Comunicado do Grupo de Lima. 07 abr. 2018c.

Comunicado do Grupo de Lima. 14 maio 2018d.

Comunicado do Grupo de Lima. 18 maio 2018e.

Declaração do Grupo de Lima. 21 maio $2018 f$.

Declaração do Grupo de Lima. 13 ago. 2018g.

Declaração do Grupo de Lima. 15 set. 2018h.

Declaração do Grupo de Lima. 04 jan. 2019a.

Declaração do Grupo de Lima 2/2019. 13 jan. 2019b

Declaração do Grupo de Lima - 003-19. 23 jan. 2019 c.

Declaração do Grupo de Lima. 04 fev. 2019 d.

. Declaração do Grupo de Lima em apoio ao processo de transição

democrática e à reconstrução da Venezuela. 25 fev. 2019 e.

$2019 f$.

Situação na Venezuela - Comunicado do Grupo de Lima. 10 mar.

. Comunicado do Grupo de Lima. 21 mar. 2019g.

Declaração do Grupo de Lima. 15 abr. 2019h. 
Declaração do Grupo de Lima. 30 abr. $2019 i$. Declaração do Grupo de Lima. 03 maio 2019j. Comunicado do Grupo de Lima. o9 maio 2019k. Declaração da XIV Reunião de Ministros das Relações Exteriores do Grupo de Lima. 06 jun. 2019l.

Declaração dos Membros do Grupo de Lima. 30 jun. 2019m.

Nota do Grupo de Lima. 30 jun. 2019n.

Declaração da XV Reunião de Ministros de Relações Exteriores do

Grupo de Lima. 23 jul. 20190.

Comunicado do Grupo de Lima. 15 ago. 2019p.

. Comunicado do Grupo de Lima. 29 ago. 2019q.

. Declaração do Grupo de Lima. 23 set. 2019r.

Declaração do Grupo de Lima. 13 out. 2019s

Repúdio à eleição do regime ilegítimo venezuelano ao Conselho de

Direitos Humanos - Comunicado do Grupo de Lima. 18 out. 2019t.

.Declaração do Grupo de Lima. 08 nov. $2019 u$.

.Declaração do Grupo de Lima. 05. jan. 2020 .

.Declaração do Grupo de Lima. 05. jan. 202ob.

.Comunicado do Grupo de Lima. 20. fev. 2020c.

.Declaração do Grupo de Lima. 01. março. 2020d.

Declaração do Grupo de Lima. 02. abr. 2020 e.

Comunicado do Grupo de Lima. 16.junh. 2020f.

Declaração do Grupo de Lima. 14 ago. 2020g.

Declaração do Grupo de Lima. 13 out. 2020h.

Disponíveis em: http://antigo.itamaraty.gov.br/notas-a-imprensa e http://antigo.itamaraty.gov.br/es/component/tags/tag/grupodelimaesp Acesso em: 20/11/2020.

Processo de Quito. Página oficial. Disponível em: https://procesodequito.org/pr Acesso em: 28/02/2021.

. Declaración de Quito sobre Movilidad Humana de ciudadanos venezolanos en la región. 2018a.

. Plan de Acción del Proceso de Quito sobre la Movilidad Humana de nacionales venezolanos en la región. 2018b.

. Declaración conjunta de la tercera reunión técnica internacional sobre movilidad humana de ciudadanos venezolanos en la región. 2019a.

. Declaración conjunta de la cuarta reunión técnica internacional sobre movilidad humana de nacionales venezolanos. Capítulo de Buenos Aires. 2019b.

. Declaración conjunta de la quinta reunión técnica internacional sobre movilidad humana de ciudadanos venezolanos en la región. Capítulo de Bogotá. 2019c.

Declaración conjunta de la sexta reunión técnica internacional sobre movilidad humana de ciudadanos venezolanos en la región. Capítulo de Santiago. 2020.

Disponíveis em: https://procesodequito.org/pr/declaracoes Acesso em: 28/02/2021.

Organización de Estados Americanos (OEA). Tratado Interamericano de Asistencia Recíproca, 2019a. Disponível em: https://www.oas.org/juridico/spanish/tratados/b-29.html Acesso em $12 / 04 / 2019$. 
Revista Brasileira de História \& Ciências Sociais - RBHCS

Vol. 13 No 26, Janeiro - Junho de 2021

OEA. CP/RES. 1137 (2245/19). Convocatoria a la Reunión del Órgano de Consulta del Tratado Interamericano de Asistencia Recíproca (TIAR), 2019b. Disponível

em:

http://scm.oas.org/doc public/SPANISH/HIST 19/CP41438So3.doc Acesso em 12/04/2020.

OEA. RC.30/RES. 1/19. Resolución de la Trigésima reunión de consulta de Ministros de Relaciones Exteriores actuando como órgano de consulta en aplicación del Tratado Interamericano de Asistencia Recíproca (TIAR), 2019c. Disponível em: https://www.oas.org/es/centro noticias/comunicado prensa.asp?sCodigo=D018/19 Acesso em 12/04/2020.

OEA. Migração. Disponível em: http://www.oas.org/pt/topicos/migracao.asp Acesso em 08/01/2021.

Recebido em Abril de 2021 Aprovado em Setembro de 2021 